\title{
Addressing key ecological questions to support policy-making in Brazil
}

\author{
Almeida, RM., Pinto, VG., Castro, MM., Divino, AC., Alves, ACA., Vasconcelos, D., \\ Magalhães Silva, MR., Mamede, N., Lima, RNS., Mello, RM., Siviero, TS., Martins, T., \\ Campos, V., Conde, BE., Brito, PS., Favoreto, FC., Vidal, LO. and Roland, F.* \\ Programa de Pós-graduação em Ecologia, Universidade Federal de Juiz de Fora - UFJF, \\ Rua José Lourenço Kelmer, s/n, Campus Universitário, CEP 36036-900, Juiz de Fora, MG, Brazil \\ *e-mail: fabio.roland@ufjf.edu.br
}

Received November 22, 2012 - Accepted December 10, 2012 - Distributed May 31, 2013

In Brazil, there is generally a lack of information flow between scientists and policy makers. Here, we address 29 ecological questions of high policy relevance in Brazil, in an attempt to encourage the participation of science in decision-making. Similar addresses have been made by British and American scientists (Fleishman et al., 2011; Sutherland et al., 2006), and it is our goal to bring such matters to the Brazilian reality. We had several meetings during an Ecosystem Ecology seminar held at the Federal University of Juiz de Fora and categorised our questions into five different topics. Brief introductory paragraphs are shown below each topic and the questions are presented subsequently without any order of relevance.

\section{Climate Change}

Brazil is the third largest greenhouse-gas (GHG) emitter in the world, but the energy system has a minor impact on GHG emissions (only about 15\%). Instead, the bulk of Brazilian GHG emissions come from agriculture, land-use change and forestry activities (IEA, 2010). Therefore, reduction in such emissions heavily relies on policies to reduce and control fire and deforestation of natural ecosystems.

- What can be done to reduce Brazilian emissions of greenhouse gases?

- How resilient are Brazilian biomes in respect to global climatic changes?

- Do the economic gains of the pre-salt oil layer exploitation offset the ecological setbacks?

- How to encourage the carbon market aiming for socio-environmental benefits?

\section{Ecosystem Services and Environmental Policy}

Ecosystems provide many benefits for human beings. However, several ecosystem services have been declining in response to unregulated exploitation of natural resources.

- How can environmental awareness be better approached in educational policies?

- What is the actual functionality of conservation actions directed to the policy of protected natural areas?

- What actions should be taken to ensure that environmental crimes are prosecuted with the severity necessary to make them unattractive?
- What actions can be taken to mitigate environmental impacts of Brazilian natural resources utilization to supply worldwide consumer market?

- How should little studied synthetic pharmaceuticals released into the ecosystems be considered in natural resources management plans?

\section{Urban Development}

Nowadays, 90\% of Brazil's gross domestic product (GDP) is created in cities (da Mata et al., 2007). In response to the urbanisation process, natural areas were and are being increasingly occupied and degraded (Amaral et al., 2012), promoting a scenario of illegal occupations and financial speculation. The total area of land required to sustain an urban region, referred to as ecological footprint, is at least an order of magnitude greater than that contained within municipal boundaries (Rees, 1992). This implies that urban regions appropriate the carrying capacity of somewhere else, creating dependencies that may be not sustainable.

- How to plan and ensure sustainability of Brazilian cities?

- How to use urban green areas as a recreational resource while concomitantly conserving them?

- What actions should be taken in order to reduce impacts of waste disposal and how can it be correctly managed?

- What actions should be taken to reverse the situation of irregular urban occupations?

\section{Water Resources}

Over the last decades, Brazil has been experiencing tremendous economic growth. Economic growth is followed by an increase in the demand of water per person (Oki and Kanae, 2006), ultimately causing deterioration of water bodies. Recently, several small to large reservoirs have been installed and the number of impoundments is expected to keep increasing in the future. In addition, both local environmental changes and global climatic changes have been changing the ecology and biogeochemistry of Brazilian inland waters (Roland et al., 2012).

- How can the immense Brazilian freshwater reserve sustainably subsidise population and economic growths?

- Do the benefits of a hydropower plant construction offset social and environmental costs? 
- Is it ecologically better to construct few large or multiple small impoundments?

- How much can flood pulses be dampened without hampering the functioning of downstream ecosystems?

- To what extent does the construction of a given reservoir change local and regional precipitation regimes?

- Is it possible to make multiple uses of reservoirs so that one use does not deteriorate another?

- How to reverse the impacts of agricultural practices in siltation and changes in the water quality of aquatic ecosystems?

\section{Wildlife and Biodiversity Conservation}

Biodiversity loss is a matter of great concern, particularly in natural ecosystems and their wild biota. Uncontrolled exploitation of natural ecosystems is leading to a gradual deterioration of biodiversity (Alho and Sabino, 2011). Brazilian environmental legislation has been inadequate with respect to biodiversity conservation.

- What actions should be taken for effective biological control in monocultures?

- How can biodiversity be enhanced in forestry areas?

- How can ecological succession be recovered or stimulated in highly anthropogenically impacted ecosystems?

- How to make it financially attractive for farmers to preserve forest patches and streams inside their properties?

- What actions should be taken to control and avoid the insertion of invasive species in natural ecosystems?

- What is the role of private initiative for the conservation and management of species?

- How to efficiently reconcile human presence and conservation of wildlife?

- What implications does the conservation of top chain predators have on ecosystem conservation?

- How to efficiently define Marine Protected Areas?

With the questions presented here, we expect to encourage future research and further that the answers are used to guide decision-making. Our broad questions embrace many other specific questions. Therefore, decision-making on a specific topic must be accomplished by answering lots of small and less complex questions, ultimately making it a multidisciplinary process. Finally, involving most diverse sectors of society is a way to solve and comprehend current environmental problems that are still unresolved.

\section{References}

ALHO, CJR. and SABINO, J., 2011. A conservation agenda for the Pantanal's biodiversity. Brazilian Journal of Biology, vol. 71, no. 1 , p. 327-335.

AMARAL, DD., VIEIRA, ICG., SALOMÃO, RP., ALMEIDA, SS. and JARDIM, MAG., 2012. The status of conservation of urban forests in eastern Amazonia. Brazilian Journal of Biology, vol. 72, no. 2, p. 257-265. http://dx.doi.org/10.1590/S151969842012000200005

DA MATA, D., DEICHMANN, U., HENDERSON, JV., LALL, SV. and WANG, HG., 2007. Determinants of city growth in Brazil. Journal of Urban Economics, vol. 62, no. 2, p. 252-272. http://dx.doi.org/10.1016/j.jue.2006.08.010

FLEISHMAN, E., BLOCKSTEIN, DE., HALL, JA., MASCIA, MB., RUDD, MA., SCOTT, M., SUTHERLAND, WJ., BARTUSKA, AM., BROWN, AG., CHRISTEN, CA., CLEMENT, JP., DELLASALA, D., DUKE, CS., EATON, M., FISKE, SJ., GOSNELL, H., HANEY, JC., HUTCHINS, M., KLEIN, ML., MARQUSEE, J., SATERSON, SAVITT, CC., STEIN, BA., WEBSTER, MS. and VEDDER, A., 2011. Top 40 Priorities for Science to Inform US Conservation and Management Policy. Bioscience, vol. 61, no. 4, p. 290-300. http://dx.doi.org/10.1525/ bio.2011.61.4.9

International Energy Agency - IEA, 2010. CO2 emissions from fuel combustion. OECD Publishing. $510 \mathrm{p}$.

OKI, T. and KANAE, S., 2006. Global hydrological cycles and world water resources. Science, vol. 313, no. 5790, p. 1068-1072. http://dx.doi.org/10.1126/science.1128845

REES, WE., 1992. Ecological footprints and appropriated carrying capacity: what urban economics leaves out. Environment and Urbanization, vol. 4, no. 2, p. 121-130. http://dx.doi. org/10.1177/095624789200400212

ROLAND, F., HUSZAR, VLD., FARJALLA, VF., ENRICHPRAST, A., AMADO, AM. and OMETTO, JPHB., 2012. Climate change in Brazil: perspective on the biogeochemistry of inland waters. Brazilian Journal of Biology, vol. 72, no. 3, p. 709-722. http://dx.doi.org/10.1590/S1519-69842012000400009

SUTHERLAND, WJ., ARMSTRONG-BROWN, S., ARMSWORTH, PR., BRERETON, T., BRICKLAND, J., CAMPBELL, CD., CHAMBERLAIN, DE., COOKE, AI., DULVY, NK., DUSIC, NR., FITTON, M., FRECKLETON, RP., GODFRAY, HCJ., GROUT, N., HARVEY, HJ., HEDLEY, C., HOPKINS, JJ., KIFT, NB., KIRBY, J., KUNIN, WE., MacDONALD, DW., MARKER, B., NAURA, M., NEALE, AR., OLIVER, T., OSBORN, D., PULLIN, AS., SHARDLOW, MEA., SHOWLER, DA., SMITH, PL., SMITHERS, RJ., SOLANDT, J., SPENCER, J., SPRAY CJ., THOMAS, CD., THOMPSON, J., WEBB, SE., YALDEN, DW. and WATKINSON, AR., 2006. The identification of 100 ecological questions of high policy relevance in the UK. Journal of Applied Ecology, vol. 43, no. 4, p. 617-627. http://dx.doi. org/10.1111/j.1365-2664.2006.01188.x 